\title{
Survivalism, collectivism and proud heritage: A study of informal arts and crafts entrepreneurship in rural Zimbabwe
}

\begin{tabular}{|c|c|}
\hline \multicolumn{2}{|c|}{$\begin{array}{l}\text { Authors: } \\
\text { Sibusiswe P. Bango }{ }^{1} \\
\text { Esinath Ndiweni } \\
\text { Laura Galloway }{ }^{3} \text { (1) } \\
\text { Helen Verhoeven }\end{array}$} \\
\hline \multicolumn{2}{|c|}{$\begin{array}{l}\text { Affiliations: } \\
{ }^{1} \text { Empretec, Zimbabwe }\end{array}$} \\
\hline \multicolumn{2}{|c|}{$\begin{array}{l}{ }^{2} \text { School of Social Sciences, } \\
\text { Heriot-Watt University, } \\
\text { United Kingdom }\end{array}$} \\
\hline \multicolumn{2}{|c|}{$\begin{array}{l}{ }^{3} \text { Edinburgh Business School, } \\
\text { Heriot-Watt University, } \\
\text { United Kingdom }\end{array}$} \\
\hline \multicolumn{2}{|c|}{${ }^{4}$ Private, United Kingdom } \\
\hline \multicolumn{2}{|c|}{$\begin{array}{l}\text { Corresponding author: } \\
\text { Laura Galloway, } \\
\text { laura.galloway@ebs.hw.ac.uk }\end{array}$} \\
\hline \multicolumn{2}{|c|}{$\begin{array}{l}\text { Received: } 02 \text { Aug. } 2017 \\
\text { Accepted: } 18 \text { Mar. } 2018 \\
\text { Published: } 23 \text { Aug. } 2018\end{array}$} \\
\hline \multicolumn{2}{|c|}{$\begin{array}{l}\text { How to cite this article: } \\
\text { Bango, S.P., Ndiweni, E., } \\
\text { Galloway, L. \& Verhoeven, H., } \\
\text { 2018, 'Survivalism, collectivism } \\
\text { and proud heritage: A study } \\
\text { of informal arts and crafts } \\
\text { entrepreneurship in rural } \\
\text { Zimbabwe', South African } \\
\text { Journal of Business } \\
\text { Management 49(1), a233. } \\
\text { https://doi.org/10.4102/ } \\
\text { sajbm.v49i1.233 }\end{array}$} \\
\hline \multicolumn{2}{|c|}{$\begin{array}{l}\text { Copyright: } \\
\text { (c) 2018. The Authors. } \\
\text { Licensee: AOSIS. This work } \\
\text { is licensed under the } \\
\text { Creative Commons } \\
\text { Attribution License. }\end{array}$} \\
\hline \multicolumn{2}{|l|}{ Read online: } \\
\hline 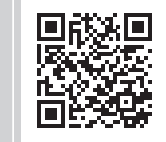 & $\begin{array}{l}\text { Scan this QR } \\
\text { code with your } \\
\text { smart phone or } \\
\text { mobile device } \\
\text { to read online. }\end{array}$ \\
\hline
\end{tabular}

Background: Entrepreneurship has most often been studied in the context of developed economies and results extrapolated to apply universally. This tells us little about entrepreneurship in other contexts, including in developing economy situations. In the developing world, entrepreneurship has been explored as a means of reducing poverty, but there has been little inspection of it from other perspectives.

Aim: This article explores the motives and experiences of arts and crafts traders in rural Zimbabwe and provides information about the purposes of the business for financial and social life from the perspectives of our research participants.

Method: The study used a qualitative methodology, conducting interviews with 12 rural arts and crafts traders.

Results: The research identifies drivers, experiences and outcomes of entrepreneurship that are explained by the unique structural and sociocultural context, and the value ascribed to business refers both to financial income and the dissemination of culture and heritage. Evidence of specific sub-Saharan modes of conducting business, reflecting the collectivity, reciprocity and strong ethnic identity characteristics of sub-Saharan African societies also emerges.

Conclusion: The article illustrates that western models of business and entrepreneurship may be limited in terms of informing us about the experiences in other contexts. We argue that research on entrepreneurship, and any policy on it in sub-Saharan Africa, takes cognisance of the non-western context and the potential for unique contextual business orientation and outcomes.

\section{Introduction}

Entrepreneurship is defined in this article as self-employment and independent business, as per studies such as the international Global Entrepreneurship Monitor (GEM) (e.g. Herrington \& Kew 2017). While the GEM compares rates of new entrepreneurship in countries across the world, there is a lack of study of the experiences of entrepreneurship in countries outside the western developed nation context (Rivera-Santos et al. 2015; Terjesen, Hessels \& Li 2016). As a consequence, our understanding of entrepreneurship is almost entirely based on western experiences of it in developed nations. Yet, in terms of rates, entrepreneurship is found to be most prevalent in the relative poverty circumstances in developing nations (Kelley et al. 2016). In sub-Saharan Africa, rates of both poverty and entrepreneurship are amongst the highest in the world, and in Zimbabwe - which is the context of this article - entrepreneurship is the largest employer and that has averted economic collapse (Chidoko et al. 2011).

The experiences and drivers of entrepreneurship in non-western economies diverge from those in developed nations - by definition, the conditions for trade vary as a consequence of variation in institutional environments. Culture and social life also play a role in this. In some areas of business studies, such as in the employment literature, it is now well established that work in African countries is influenced by local culture, and international businesses account for this (e.g. Kamoche 2011). In the sub-Saharan African context in particular, a social system that prioritises collectivism, community and reciprocity is observed (e.g. Andersson 2006; NewenhamKahindi 2009), as are strong extended family-based relationships of trust in and responsibility for each other (Andersson 2006; Rivera-Santos et al. 2015). Beyond this, sub-Saharan African people are known to have strong ethnic identity (Anakwe 2002; Rivera-Santos 2015). To date, however, studies have made little reference to the potential of the sociocultural environment to 
impact on the experiences and outcomes of entrepreneurship in the heterogeneous but distinctly non-western contexts of sub-Saharan Africa (Jackson \& Amaeshi 2008; Mufane 2003). Therein lies the purpose of this article.

Social values and identity are expressed through shared practices and in arts and cultural artefacts (e.g. Belfiore \& Bennett 2010). Consequently, the aim of the empirical work was to explore experiences of entrepreneurship in an industry based on tradition and heritage and in one of the most economically challenged areas on the planet. Reporting an exploratory study of a small sample of arts and crafts firms in rural Zimbabwe, this article thus contributes to setting a research agenda to facilitate better understanding of the experiences and value of local business activity to local communities in a non-western setting.

The article starts with a review of the context of Zimbabwe and of recent literature on business and self-employment in African nations. Following this, the methodology employed for the empirical work is described. Data from a small sample of arts and crafts entrepreneurs in rural Zimbabwe are reported, followed by a discussion of the implications of emerging themes. The article concludes with summary outcomes about the business activities reported, including mixed motivations for ongoing business, and nuance in terms of business structure and operations. In particular, sociocultural influences on business behaviours require further investigation and we call for research and policy engagement with the realities of African business in social context, found here to be rather different amongst the sample of rural Zimbabweans than is implied by the normative western individualist entrepreneur.

\section{The Zimbabwean context}

In 1980, the independent nation of Zimbabwe emerged from a century of British colonisation, apartheid and exploitation. Lack of economic and social infrastructure and policy, along with civil unrest and conflict, has impeded economic development, as has alienation from the global community in response to allegations of human and civil rights abuses (World Bank 2016). Over the last four decades, these have all played a part in the economic decline of the country and the Zimbabwean economy was considered in crisis during the decade 1998-2008 (CIA [Central Intelligence Agency] 2014). In particular, the collapse of the agriculture industry following independence and redistribution of land, the deterioration of gold production by $75 \%$ by the end of 2008 ; and inflation at more than 2 million per cent in the same year devastated the economy (MDTF [Multi Donor Trust Fund] 2008). Cumulatively, these were caused by, and caused further, exodus of skilled workers from Zimbabwe, leading to further decline. The lack of key industries, hyperinflation and a lack of skills took their toll, and unemployment in the formal economy rose to between $80 \%$ and $95 \%$ according to Dekker (2009). Following a period of recovery, Zimbabwe has suffered further setbacks recently as a consequence of natural disasters, weak policy, debt and further economic sanctions. Poverty in Zimbabwe is amongst the worst in the world; according to the World Bank (2016), $72 \%$ of Zimbabweans live in extreme poverty ( $84 \%$ in rural areas), defined as living on $\$ 2$ or less per day. It is from this calamitous economy that the Zimbabwean informal entrepreneur has emerged (Ndiweni \& Verhoeven 2013).

The International Labour Organization (ILO 2017) describes informal work as that which is unregulated and casual and most of it is conducted as self-employment or business (i.e. entrepreneurship as defined in this article). Today, unemployment in the Zimbabwean formal economy is estimated at around $75 \%$ amongst the population of 15 million (Murisa \& Chikweche 2013), yet the UN (2014) puts labour force participation at more than $80 \%$ for both men and women. Consequently, there is no doubt that the scale of informal entrepreneurship is substantial (Chidoko et al. 2011); indeed, Murisa and Chikweche (2013) estimate that it is now the country's largest employer, a situation mirrored throughout sub-Saharan Africa (Chen 2007).

\section{Sub-Saharan entrepreneurship}

While defined in this article as self-employment and independent business, conceptualisations of entrepreneurship are associated with notions of innovation and opportunity. Distinguishing between these and survivalist and otherwise basic forms of self-employment has featured throughout entrepreneurship scholarship. Global Entrepreneurship Monitor, for instance differentiates between opportunity and necessity entrepreneurship, the former involving exploiting opportunities to create financial value in innovative and economically contributory ways; the latter involving independent trading in response to few reasonable alternatives (Herrington \& Kew 2017). Similar to these, other authors such as Minniti and Levesque (2010) and Ziegler (1985) refer to innovative versus imitative entrepreneurship; and Bhaumik and Selarka (2012) and Schillo (2011), for example refer to innovation versus bricolage. Poverty in Africa is compounded, according to Mitra and Sagagi (2013), by low national gross domestic product (GDP), poor health and lack of safe water and culminates for populations in less food, low rates of literacy and low-skill levels relative to the rest of the world. None of these is ever associated elsewhere with capacity for innovation and opportunity-oriented entrepreneurship. Instead, this has been found to be most likely in circumstances characterised by good levels of employment and the associated availability of skills, experience and resources (Sanandaji \& Sanandaji 2014). Alternatively, survivalist, informal entrepreneurship is more rationally indicated in the absence of employment and resource and support infrastructure. Certainly, we know that self-employment in the developed world peaks during times of economic decline (e.g. Bögenhold \& Staber 1991), and that the highest rates of self-employment globally are in the developing nations (Earle \& Sakova 2000; Kelley et al. 2016). In a context such as Zimbabwe, it is informal entrepreneurial activities that predominate, and this is how many have survived, and 
continue to survive, during economic crisis and without a robust welfare system (ILO 2002; Ndiweni \& Verhoeven 2013). As these conditions prevail, economic development seems unlikely.

On the other hand, according to Portes, Castells and Benton (1989), the recovery and development of formal economy can be brought about by ongoing informal activities that prompt economic development and infrastructure. This is the premise of one of the main strands of thought on poverty and entrepreneurship; according to Bruton, Ketchen and Ireland (2013:688), for example, 'market-based solutions such as entrepreneurship offer the best opportunity to create substantial and significant positive change within poverty settings'. Thus, along with others, such as Brixiova (2010), Abubakar and Mitra (2013) and Tobias, Mair and BarbosaLeiker (2013), the claim is that opportunity-oriented, economically value-adding entrepreneurship can be prompted by informal entrepreneurship as a desperation activity in poverty circumstances. Adom (2014) reports that threequarters of his sample of Ghanaian informal workers, though driven by need, exhibited opportunity-based motives going forward in their self-employed activities. This supports the idea that opportunity-oriented entrepreneurship can emerge from survivalism, and, indeed, that entrepreneurship can act as a solution to poverty. This idea is also found in GEM; in the sub-Saharan African context specifically, Herrington and Kelley's GEM report (2013:9) acknowledges the survivalist origins of most entrepreneurial activity in the areas studied, but also notes that business creation is nevertheless 'invigorating the region with new opportunities'.

These proposed links between informal, survivalist entrepreneurship and economic development have led to government and other agency interest in how it might best contribute to recovery in the Zimbabwean economy (e.g. Chidoko et al. 2011). Consequently, agencies, such as Empretec, initially funded by the United Nations Development Programme, have emerged, and in 2005 the Zimbabwean government established the Ministry of Small and Medium Enterprises. Despite these, various challenges remain, and are identified throughout the academic and stakeholder literatures. Studies have explored issues such as the lack of access to finance, low skills, inadequate financial and physical infrastructure, lack of labour legislation and business and institutional support (e.g. Canagarajah \& Sethiraman 2001; Tibaijuka 2005). Elsewhere, there are similar calls to improve the conditions for entrepreneurship throughout sub-Saharan Africa (e.g. Nagler \& Naude 2014 on enterprise education; and Murisa \& Chikweche 2013, on provision of microfinance). These and other studies tend to treat entrepreneurship as a homogenous concept though, with implicit assumption that entrepreneurship in sub-Saharan Africa will be the same - or at least similar - to western entrepreneurship. This is not necessarily the case. Indeed, even in western contexts, there is huge variation in terms of the types, experiences, drivers and outcomes of entrepreneurship. Regardless of location, we know that informal entrepreneurship can look very different from traditional notions of business venturing and even regular (formal) self-employment (consider a mini-cab driver and Bill Gates). The potential for variation between developed and developing nation experiences of entrepreneurship is highly likely therefore. Specific to this article, the rural Zimbabwean environment suffers from widespread severe poverty, and thus from a business point of view, most trade is small scale, low financial value and local; in fact, up to twothirds of 'businesses' do not have a bank account (Murisa \& Chikweche 2013). This is a very different environment for entrepreneurship than that described in western studies. Moreover, variation in sociocultural life diverges substantially from the western world too.

Macro studies of culture and social and organisational life, such as Hofstede (2001) and House et al. (2004), find western cultures individualistic and performance oriented. Congruent with this, western approaches to business hold that the purpose of entrepreneurship is to add financial value, measured at the unit level - most often the firm or the entrepreneur (Bygrave 1994; Steyaert \& Katz 2004). According to Wiklund and Shepherd (2003), even when other features and outcomes of entrepreneurship are included in analyses, they are considered in addition to financial outcomes. Thus, we have a research base in which most empirical work has focused on western nation contexts, and on the financial value-adding potential and experiences of entrepreneurial activity. But there is assertion that there are other priorities and outcomes of entrepreneurship, and indeed, that financial drivers are not a priori even in western nations (Ramoglou \& Tsang 2016).

In the sub-Saharan African context specifically, there is considerable evidence in the sociology literature that social values, practices and cultures of sub-Saharan Africa are substantially different from those in developed western nations, involving greater collaboration, mutuality and group support (Andersson 2006). This is summarised in the conceptualisation of ubuntu. Ubuntu translates as 'a person is a person ... through others' (Moloketi 2009:243), and is explained as the interconnection of people via compassion, loyalty and humanity (Nwagbara 2012; Nzelibe 1986). Mufane (2003) describes ubuntu as promoting feelings of harmony, community and safety. As reported in the employment literature, this has a direct effect on working behaviour. Andersson (2006) and Kamoche (2011) find that work in subSaharan Africa involves collaboration, relationships and mutuality, and note the divergence from the individualism of western socio-economic philosophy and systems. Similarly, Kamoche (2011) and Newenham-Kahindi (2009), for example find that international companies have reaped best outcomes from employees where organisational policies incorporate local African values and practices.

It seems reasonable to expect that sociocultural values and practices are as likely to impact entrepreneurship as employment; as Jackson and Amaeshi (2008) note, entrepreneurship in sub-Saharan African cultures may not be 
based on the individualistic model of the west, and might instead involve collaboration and collectivism to a greater extent. Beyond the studies of Kim et al. (2016) and Mangaliso (2001) on how ubuntu might facilitate competitive advantage for firms, there is little exploration of the effect of African cultural practices on entrepreneurship. A notable further exception is the research reported in Rivera-Santos et al. (2015) that suggests that the unique cultural and economic circumstances of sub-Saharan Africa, of extreme poverty and a collectivist culture, lead to compassionate and socially oriented entrepreneurial activities. Thus, while not precluding economic drivers, the socio-economic environment may well encourage other social and cultural potentials. One such nonfinancial driver, asserted by Maphosa (1998), is concern for the maintenance of traditional culture and heritage. In a context such as Zimbabwe, with a history of colonial rule and strong indigenous ethnic identity and allegiance (Anakwe 2002), we might anticipate the possibility of expression of this emerging in entrepreneurship. Further, it seems reasonable that if this is the case, arts and crafts as a sector would be likely to include entrepreneurship thus inclined.

\section{Research agenda}

Our current understanding of entrepreneurship is restricted largely to that based on economic drivers and outcomes only and almost exclusively entrepreneurship has been studied as per western conceptualisations and expression of it - that is, it is an individualistic activity, the purpose of which is to generate financial value at the unit level, and the success of which can be measured in financial and ultimately economic terms. In turn, this has also led to a situation whereby theoretical development in the field of entrepreneurship is similarly limited to the economic (Anderson 2015). But as Andersson (2006) points out, sociological approaches to understanding entrepreneurship may be revelatory. In her study, she found migrant Malawian informal entrepreneurship related to 'the social organization of the parallel migrant labour market rather than as an outcome of the free workings of the forces of supply and demand' (p. 395), that is, as sociological rather than economic phenomena. Thus, there is a rationale for exploring entrepreneurship in and for social context, and therein lies the purpose of this qualitative exploratory study in rural Zimbabwe. The following section describes the methodology employed to investigate entrepreneurship in an extremely economically marginalised geographic location, and in a sector specifically focused on arts and heritage amongst a culturally marginalised population.

\section{Methodology}

The empirical work reported in this article explores the experiences and perceptions of a small sample of rural Zimbabwean entrepreneurs. A qualitative approach was identified as most appropriate as it would reveal the perspectives of the people involved and allow for matters to emerge that may not have been previously anticipated in the research design or suggested by the literature (Salkind 2014).
During the course of 1 week in summer 2016, 12 interviews were conducted by one of the researchers - a native of Zimbabwe. Guided by a basic structural framework that included the topics self-employment, entrepreneurship, arts and crafts and heritage and culture, these interviews were semistructured and conversational to allow participants to tell their stories (Bertaux 1981; Stake 1995). All interviews were recorded and then translated and transcribed.

\section{The sample}

The sample of participants was sourced via the United Nations' business and employment support agency, Empretec. Specifically, a small sample of arts and crafts entrepreneurs from rural Zimbabwe who had approached Empretec for support or advice was invited to participate. This sampling method clearly risks self-selection bias, and indeed, can only uncover the opinions and experiences of those who had a relationship with Empretec and visited their office during the week of the fieldwork in 2016. As the research sought not to compare experiences nor extrapolate representativeness, this was acceptable; the experiences and opinions of self-selecting Empretec clients are as valid as any in terms of providing testimony about their specific motivations for starting and maintaining their business and their unique experiences. Summary details of the 12 participants are provided in Table 1. The first thing of note is that the age of the firms varies widely, ranging from the oldest of 26 years, to very recent start-ups. Additionally, there is substantial variation in terms of the numbers employed in the firms. A western interpretation of this data would normally consider the respondent the 'owner', but the structure of the firms - if they can be called firms at all - appears to be somewhat different amongst this sample. This is discussed in greater detail in the following section.

An analysis was conducted by each of the researchers the fieldworker and three other experienced qualitative researchers - considering the transcripts independently. Then, using a collaborative approach amongst the four researchers, the three-step analysis described in Miles and Huberman (1994) of data reduction, data presentation and explanation was applied and emerging themes were identified. Broadly, these themes referred to the purposes of

TABLE 1: Summary sample data.

\begin{tabular}{lccl}
\hline Participant & $\begin{array}{c}\text { Age of } \\
\text { 'firm' }\end{array}$ & $\begin{array}{c}\text { Number of people engaged } \\
\text { or employed in the firm }\end{array}$ & Core business \\
\hline Zuwa & 26 & 2 & Weaving \\
Rudo & 23 & 3 & Pottery \\
Duncan & 20 & 4 & Arts and crafts \\
Dambudzo & 5 & 10 & Natural forest products \\
Thomas & 4 & 7 & Leather goods \\
Mildred & 3 & 6 & Pottery \\
Chipo & 3 & 15 & Traditional health foods \\
Ruth & 3 & 4 & Batik dying \\
Florence & 3 & 17 & Arts and crafts \\
ljahman & 2 & 2 & Craftwork \\
Skhethiwe & 1 & 9 & Jewellery \\
Dorcal & 0.5 & 5 & Arts and crafts manufacture \\
\hline
\end{tabular}


entrepreneurship and the experiences of entrepreneurship, and in particular business structures, business skills and access to finance and support. These are discussed in the next section.

\section{Ethical consideration}

The research conducted was compliant with the policy on ethics in research at Heriot-Watt University.

\section{Results}

\section{The purposes of entrepreneurship}

As expected, there was much evidence that the business activities of participants in this research were driven by financial need in the absence of alternative sources of income to live on. Most of the participants mentioned that they did not make much money from their business activities, but what they did make was essential and required for survival; almost all of the participants cited specifically that they could buy food for themselves and their families from the income generated. The comments of Thomas and Skhethiwe are typical:

'This business has sustained my family for years. I can buy food, clothes and all that my family needs.' (Thomas, 7-person 'firm', leather goods)

'It's giving me money to sustain the family. I can afford to buy clothes, shoes and food for my family.' (Skhethiwe, 9-person 'firm', jewellery)

These responses reflect a situation not dissimilar to that for any entrepreneur regardless of location, but in these cases, the context is of extreme deprivation without access to alternative support. Indeed, in response to being asked her main motivation for business, Skhethiwe expresses it simply as 'poverty'.

The survivalism clearly evidenced was not the only motivation for entrepreneurship, however. There was much evidence of artisanship, artistry, pride and traditionism amongst respondents. For example, Zuwa states, 'I make beautiful products', while Florence relates, 'I produce the finest art and each sculpture gives a picture and it tells a story'. This perspective is common amongst art and traditional productbased businesses, and it was a prevalent position amongst those for whom the realisation of their artistry comprised an essential reaction to adversity. Thus, alongside the mandatory nature of their business activities for income and survival, participants expressed additional motivators associated with pride and tradition. This suggests that survivalism and other motivations, in these cases particularly application and maintenance of traditional arts practice, are not mutually exclusive. As Chipo explains it, 'Arts and crafts ... preserves our culture'.

\section{The experiences of entrepreneurship}

The business structures described by participants do not seem to comprise owners and employees. Despite the data in Table 1 about the number of people involved in each 'firm', there was no evidence of waged employment in any sense, just collective effort and shared income of co-self-employed stakeholders. These were described as 'communities' and groups and roles of individuals could change depending on the tasks required at a given time. The evidence within the data suggests therefore that the participants engaged in the 'firms' were actually more akin to continually changing cooperatives. No participant described an 'owner/employees' structure. Instead, what was most often described was a group effort amongst different individuals, and a share of income and profit. This idea of groups of people working together suggests a flat structure in which participants are self-employed but cooperative. A part of this group approach may be industry based; several interviewees identified that the creative arts and crafts processes are staged and different people are engaged in the different stages. For example, in her Forest Products business, Dambudzo (10-person 'firm', Natural Forest Products) explains:

'some go in the bush to collect seeds, some press, produce, using machines, and some sell. You allocate duties to different people.'

Elsewhere, this demarcation of duties was less clear. For example, Rudo describes a collective effort in all the stages in her 3-person Pottery business:

'Everyone is involved in making the Hari [clay pots], and then we all sell together. '

Whether industry-specific or peculiar to rural or African context, this group phenomenon seemed common and in line with the tradition of collectivity and ubuntu. As Dorcal notes of his 5-person Arts and Crafts Manufacturing, 'a one man band is difficult. You need to form a group'.

These comments imply that individual business effort is higher risk than collective activity in terms of generating income. This resonates with the safety and mutual responsibility also implied by ubuntu.

Another interesting outcome in terms of the realities and experiences of the participants in this research is that there was much evidence of the application of business acumen. The identified survivalism underpinning business in this highly marginalised environment might be considered suggestive of a lack of sophistication in terms of business activity. On the contrary though, just over half of the participants mentioned, unprompted, that there must be proper research and engagement with the market for the business to be successful. For example, Florence's and Rudo's comments are typical:

'First check the design of your product, then research about the market for it, then start marketing.' (Florence, 17-person 'firm', Arts \& Crafts)

'Business starters should study their market first before venturing into business.' (Rudo, 3-person 'firm', Pottery) 
Another business issue identified was that one should not expect immediate or consistent success. As Dambudzo (10-person 'firm', Natural Forest Products) notes:

'Starting a business is not always easy. There are profits and losses. You just have to be committed and don't give up.'

This is pertinent particularly in the context of necessity for survival. Mildred's comment in the context of her 6-person Pottery business resonates:

'You have to be patient. There will be ups and downs. So you have to be patient. And you shouldn't run to eat the profits. Invest them instead.'

The skills and strategising reported by these participants lend support to the idea that even when prompted by and located in a context of survivalism, the experience of business develops skills and attitudes that might contribute to further business. Notwithstanding this though, resourcing was identified as an issue. No participant mentioned grant or subsidy; perhaps, in the absence of state welfare, there is no conceptualisation of it as a possibility. Most of the 12 participants identified that their firms suffered from a lack of funds for sustainability and growth, but where this was identified as a support need it was always expressed in terms of improving access to funding, rather than direct aid. The lack of formalisation in the economy - the informal nature of the entrepreneurship observed - was identified as a particular concern, particularly in the context of bank lending. Chipo, Ijahman, Skhethiwe, Florence and Mildred all explained that despite an absence of collateral, policy on and access to bank loans would improve their sustainability. The informal nature of many of the businesses in the current study was itself cited as the source of the lack of collateral. According to Ijahman (2-person 'firm', Craftwork), this further stymies the potential of his business:

'Give us a place to sell our products permanently... That would enable us to get loans for capital, in order to expand.'

The participants also commonly reported the challenge of accessing markets. For arts and crafts, this was most often cited as a need for increased markets locally, and indeed, Zuwa advocates that government should insist that supermarkets retail a minimum proportion of local products. Identification of the need for arts and crafts space was common, and some comments expressed that this would facilitate both local and external, including international, market opportunities:

'We need many fairs and markets. We need convenient places to sell.' (Ruth, 4-person 'firm', Batik Dying)

'We need exposure to international markets.' (Rudo, 3-person 'firm', Pottery)

'They need to create opportunities to exhibit locally and outside the country.' (Dorcal, 5-person 'firm', Arts and Crafts Manufacturing)

\section{Discussion}

The literature on entrepreneurship in sub-Saharan Africa is limited. The existing research identifies that entrepreneurship - or more accurately, informal entrepreneurship - is essential for some for survival. This study of rural Zimbabwean business activity generally corroborates this, and within the small sample included in this study, there is evidence that these activities have been maintained by some people for considerable time.

In this small study, there is suggestion of social influences on the experiences and outcomes of business not commonly encountered in the (western) business literature generally. Most of the participants in this study were operating informal ventures, with a structure somewhat different from that of western conceptualisations of business. In this study, all of the participants were conducting their business activities alongside others in the same position, and had organised themselves into structures more resonant of collectives than hierarchy. The influence of culture, particularly the collaborative, shared responsibility and group safety associated with ubuntu was reported. Any development or other intervention with sub-Saharan business might be best served by cognisance of this as an underpinning precept. Work activities, including business, seem to be shaped by a collaborative tradition, and understanding and intervention must be informed by this rather than rely on conceptualisations of the western individual and competitive entrepreneur.

This study also supports the contention, found in Maphosa (1998), for example that there is a contribution made by entrepreneurship in this rural context to the maintenance of traditional culture. For the arts and crafts sector participants in this study, a pride in quality and provenance of their products was demonstrable. The participants engaged in their business activities in order to secure income and had chosen arts and crafts because they had skills in these areas and a desire to contribute to their culture and heritage. This was expressed as a desire to maintain traditional skills and disseminate traditional culture locally. The participants also expressed a desire to reach the external world too - to exhibit this identity and culture as expressed through their art. What was limiting this was not a lack of ambition or even business skills. On the contrary, the informality of the business activities observed did not suggest a lack of appreciation, understanding or sophistication in terms of business functions or requirements. Several participants, unsolicited, expressed desire and suggested means by which business expansion might be achieved. In terms of what this tells us about survivalist-based informal business, there is thus some support from the data for the assertion in studies such as Herrington and Kelley's (2013) sub-Saharan GEM report that necessity, and even survivalist, business has the potential to add value by acting as an antecedent to further, potentially financially lucrative, entrepreneurship. The data presented here do not, however, suggest that this itself is sufficient for realisation. A lack of access to international markets was entirely thwarted by the environment. Zimbabwe has very limited international tourism, and for these participants, little means by which exporting could be facilitated. The participants also stated that the potential for expansion of 
any type was limited by a lack of access to funding. These were considered limitations borne of the informal nature of their businesses, and until legislative infrastructure allows formalisation of businesses so that they can access finance, and until there is infrastructure and support of markets, then expansion will continue to be limited. Indeed, the collective ventures described will continue to provide a hand to mouth living for participants.

In brief, the lack of institutions to support business activities in rural Zimbabwe is implicated as the impediment to the realisation of any international potential in these cases. The will of the informal entrepreneurs regarding opportunitybased expansion is not in question, but the realisation of any opportunity-oriented ambitions will be thwarted by the lack of institutional environment characteristic of Zimbabwe. While other sub-Saharan African nations are beginning to develop such infrastructure, Zimbabwe is far from it, and rural Zimbabwe further still.

\section{Concluding remarks}

This study provides a small snapshot of the lives of 12 rural Zimbabweans engaged in arts and crafts entrepreneurship. The study is obviously limited in terms of generalisability because of its qualitative approach and small sample size. Consequently, while the testimonies reported refer to arts and crafts and to rural Zimbabwe, they do not claim to represent the general experiences of either one.

Despite these limitations, the study makes several pertinent contributions, however. First, there is support for Adom (2014) that even in the survivalist situation explored here, motivations do not seem to be exclusively necessity based and that complexity and overlap of positive and negative entrepreneurship motivators are experienced. In addition, the testimonies of participants suggest divergence from western experiences of entrepreneurship in terms of structure, infrastructure and day-to-day operations of business activities. The essentialism described, in particular, requires further exploration whether we are to engage productively with understanding businesses in this type of environment. Practices such as $u b u n t u$, require further exploration in terms of its influence on business and indeed its role in survivalism. Where there is a rationale for intervention to support the informal sector, such as to provide better access to microfinance (as per Murisa \& Chikweche 2013) or enterprise education for younger generations (as advocated by Nagler \& Naude 2014), engagement with the unique cultural context is also suggested as critical.

Murisa and Chikweche (2013) assert that there is a need in Zimbabwe to challenge the culture of donor dependency and encourage and support entrepreneurship as a self-sustaining economic model. In response, based on the outcomes of this small exploratory study, we suggest that our participants exhibit much enterprise already. We would further recommend that, given the specific culture, traditional western methodologies in terms of support and training may be less appropriate than those that might be designed with a specific cultural 'fit'. Support (including policy potentially) therefore is advised to take account of traditional collectivebased values and practices and strong ethnic identity and allegiance, instead of an assumption of individualism and competition as per western business practices. Similarly, outcomes beyond economic survival appear to be part of the value attributed to the entrepreneurship explored here. Further research on the prioritisation of financial goals versus cultural and social ones might be revealing, especially in the context of a developing nation and the forces of globalisation and cultural assimilation. Finally, the article provides us with contribution of data that expose another view of how entrepreneurship actually exists in the world, further contributing non-western perspectives from which we might all learn.

\section{Acknowledgements Competing interests}

The authors declare that they have no financial or personal relationships which may have inappropriately influenced them in writing this article.

\section{Authors' contributions}

All authors contributed to all aspects of the research and writing up. Fieldwork was mostly conducted by S.P.B. and E.N. The analysis was conducted by E.N., H.V. and L.G. The writing of the article was done mainly by L.G.

\section{References}

Abubakar, Y.A. \& Mitra, J., 2013, 'The venturesome poor and entrepreneurial activity in Nigeria: The role of consumption, technology and human capital', Internationa Journal of Entrepreneurship and Innovation 14(4), 235-254. https://doi.org/ 10.5367/ijei.2013.0130

Adom, K., 2014, 'Beyond the marginalization thesis: An examination of the motivations of informal entrepreneurs in sub-Saharan Africa - Insights from Ghana' International Journal of Entrepreneurship and Innovation 15(2), 113-126. https:// doi.org/10.5367/ijei.2014.0144

Anakwe, U.P., 2002, 'Human resource management practices in Nigeria: Challenges and insights', International Journal of Human Resource Management 13(7), 1042-1059. https://doi.org/10.1080/09585190210131285

Anderson, A.R., 2015, 'Conceptualising entrepreneurship as economic "explanation" and the consequent loss of "understanding", International Journal of Busines and Globalisation 14(2), 145-157. https://doi.org/10.1504/IJBG.2015.067432

Andersson, J.A., 2006, 'Informal moves, informal markets: International migrants and traders from Mzimba district, Malawi', African Affairs 105(420), 375-397. https:// doi.org/10.1093/afraf/adi128

Belfiore, E. \& Bennett O., 2010, The social impact of the arts: An intellectual history Palgrave Macmillan, London.

Bertaux, D., 1981, Biography and society: The life history approach in the social sciences, Sage, London.

Bhaumik, S. \& Selarka, E., 2012, 'Does ownership concentration improve M\&A outcomes in emerging markets?, Evidence from India', Journal of Corporate Finance 18, 717-726. https://doi.org/10.1016/j.jcorpfin.2012.04.001

Bögenhold, D. \& Staber, U., 1991, 'The decline and rise of self-employment', Work, Employment and Society 5(2), 223-239. https://doi.org/10.1177/09500170 91005002005

Brixiova, Z., 2010, 'Unlocking productive entrepreneurship in Africa's least developed countries', African Development Review 22(3), 440-451. https://doi.org/10.1111/ j.1467-8268.2010.00255.x.

Bruton, G.D., Ketchen Jr, D.J. \& Ireland, R.D., 2013, 'Entrepreneurship as a solution to poverty', Journal of Business Venturing 28(6), 683-689. https://doi.org/10.1016/j. jbusvent.2013.05.002

Bygrave, W.D., 1994, The portable MBA in entrepreneurship, John Wiley \& Sons, Hoboken, NJ.

Canagarajah, S. \& Sethiraman, S.V., 2001, Social Protection and the informal sector in developing countries: Challenges and opportunities, Social protection Discussion Paper Series, Social Protection Unit, Human Development Network, The World Bank, Washington DC. 
Chen, M.A., 2007, Rethinking the informal economy: Linkages with the formal economy and the formal regulatory environment, Department for Economic and Social Affairs Working Paper No. 46, New York.

Chidoko, C., Makuyana, G., Matungamire, P. \& Bemani, J., 2011, 'Impact of the informal sector on the current Zimbabwean economic environment', International Journal of Economics and Research 2(6), 26-28.

CIA (Central Intelligence Agency), 2014, The World Factbook: Zimbabwe, viewed 23 June 2014, from https://www.cia.gov/library/publications/the-world-factbook/ geos/zi.html

Dekker, M., 2009, Livelihoods and economic crisis: The case of smallholder farmers in Zimbabwe (1999-2008), paper presented at Conference on Economic Development in Africa 22-24 March, Centre for the Study of African Economies, University of Oxford, Oxford UK.

Earle, J.S. \& Sakova, Z., 2000, 'Business start-ups or disguised unemployment? Evidence on the character of self-employment from transition economies', Labour Economics 7(5), 575-601. https://doi.org/10.1016/S0927-5371(00)00014-2

Herrington, M. \& Kelley, D., 2013, African entrepreneurship, sub-Saharan African regional report 2012, Global Entrepreneurship Research Association, viewed 23 June 2014, from www.gemconsortium.org

Herrington, M. \& Kew, P., 2017, Global entrepreneurship monitor executive report, Global Entrepreneurship Research Association, viewed January 2018, from www. gemconsortium.org

Hofstede, G., 2001, Culture's consequences: Comparing values, behaviors, institutions, and organizations across nations, 2nd edn., Sage, Thousand Oaks, CA.

House, R.J., Hanges, P.J., Javidan, M., Dorfman, P.W. \& Gupta, V. (eds.), 2004, Culture, leadership, and organizations: The GLOBE study of 62 societies, Sage, Thousand Oaks, CA.

ILO (International Labour Organization), 2002, Women and men in the formal economy: A statistical picture, employment sector, International Labour Office, Geneva.

ILO, 2017, Informal economy, viewed 03 February 2017, from http://www.ilo.org/ global/topics/employment-promotion/informal-economy/lang--en/index.htm

Jackson, T. \& Amaeshi, K., 2008, 'Untangling African indigenous management: Multiple influences on the success of SMEs in Kenya', Journal of World Business 43(4), 400-416. https://doi.org/10.1016/j.jwb.2008.03.002

Kamoche, K., 2011, 'Contemporary developments in the management of human resources in Africa', Journal of World Business 46(1), 1-4. https://doi.org/ 10.1016/j.jwb.2010.05.011

Kelley, D., Singer, S. \& Herrington, M., 2016, Global entrepreneurship monitor, Executive Report 2015/16, Global Entrepreneurship Research Association, Boston, MA

Kim, P.H., Wennberg, K. \& Croidieu, G., 2016, 'Untapped riches of meso-level applications in multilevel entrepreneurship mechanisms', The Academy of Management Perspectives 30(3), 273-291. https://doi.org/10.5465/amp.2015.0137

Mangaliso, M.P., 2001, 'Building competitive advantage from ubuntu: Management lessons from South Africa', Academy of Management Perspectives 15(3), 23-33. https://doi.org/10.5465/ame.2001.5229453

Maphosa, F., 1998, 'Towards the sociology of Zimbabwean indigenous entrepreneurship', Zambeiz 25(2), 173-190.

MDTF (Multi Donor Trust Fund), 2008, Zimbabwe emergency recovery program, Draft 2, September, World Bank, Harare.

Miles, M. \& Huberman, M., 1994, Qualitative data analysis: An expanded sourcebook Sage, Thousand Oaks, CA

Minniti, M. \& Lévesque, M., 2010, 'Entrepreneurial types and economic growth', Journal of Business Venturing 25(3), 305-314. https://doi.org/10.1016/j.jbusvent 2008.10.002

Mitra, J. \& Sagagi, M., 2013, 'Introduction: The changing dynamics of entrepreneurial Africa', International Journal of Entrepreneurship and Innovation 14(4), 211-218. https://doi.org/10.5367/ijei.2013.0131

Moloketi, G.R., 2009, 'Towards a common understanding of corruption in Africa' Public Policy and Administration 24(3), 331-338. https://doi.org/10.1177/095207 6709103814
Mufane, P., 2003, 'African culture and managerial behaviour: Clarifying the connections', South African Journal of Business Management 34(3), 17-28.

Murisa, T. \& Chikweche, T., 2013, 'Entrepreneurship and micro-finance in extreme poverty circumstances - Challenges and prospects: The case of Zimbabwe', Journal of Developmental Entrepreneurship 18(1), pp. 1-30. https://doi.org/10.1142/ S1084946713500015

Nagler, P. \& Naude, W., 2014, Young entrepreneurs in rural Africa: Prevalence, determinants, productivity, Discussion Paper No. 8564, Institute for the Study of Labor, Maastricht.

Ndiweni, E. \& Verhoeven, H., 2013, 'The rise of informal entrepreneurs in Zimbabwe: Evidence of economic growth or failure of economic policies?', African Journal of Accounting, Auditing and Finance 2(3), 260-276. https://doi.org/10.1504/AJAAF. 2013.057636

Newenham-Kahindi, A., 2009, 'The transfer of ubuntu and indaba business models abroad: A case of South African multinational banks and telecommunication services in Tanzania', International Journal of Cross Cultural Management 9(1), 87-108. https://doi.org/10.1177/1470595808101157

Nwagbara, U., 2012, 'Leading a post-modern African organization: Towards a model of prospective commitment', Journal of Pan African Studies 4(9), 67-84.

Nzelibe, C.O.C., 1986, 'The evolution of African management thought', International Studies of Management and Organization 16(2), 6-16. https://doi.org/10.1080/0 0208825.1986 .11656427

Portes, A, Castells, M. \& Benton, L., 1989, The informal economy: Studies in advanced and less developed countries, The Johns Hopkins University Press, Baltimore, MD.

Ramoglou, S. \& Tsang, E., 2016, 'A realist perspective of entrepreneurship: Opportunities as propensities', Academy of Management Review 41, 410-434. https://doi.org/ 10.5465/amr.2014.0281

Rivera-Santos, M., Holt, D., Littlewood, D. \& Kolk, A., 2015, 'Social entreprenurship in sub-Saharan Africa', The Academy of Management Perspectives 29(1), 72-91. https://doi.org/10.5465/amp.2013.0128

Salkind, N.J., 2014, Exploring research, 8th edn., Pearson Education Ltd., Harlow, Essex.

Sanandaji, T. \& Sanandaji, N., 2014, Super entrepreneurs and how your country can get them, Centre for Policy Studies, London.

Schillo, S., 2011, 'Entrepreneurial orientation and company performance: Can the academic literature guide managers?', Technology Innovation Management Review, 1(2) 20-25, http://timreview.ca/article/497

Stake, R.E., 1995, The art of case study research, Sage, London.

Steyaert, C. \& Katz, J., 2004, 'Reclaiming the space of entrepreneurship in society: Geographical, discursive and social dimensions', Entrepreneurship \& Regional Development 16(3), 179-196. https://doi.org/10.1080/0898562042000197135

Terjesen, S., Hessels, J. \& Li, D., 2016, 'Comparative international entrepreneurship: A review and research agenda', Journal of Management 42(1), 299-344. https:// doi.org/10.1177/0149206313486259

Tibaijuka, A.K., 2005, Report of the fact finding mission to Zimbabwe to assess the scope and impact of operation Murambatsvina by the UN special envoy on human scope and impact of operation Murambatsvina by the UN special envoy on human
settlement issues in Zimbabwe, viewed 10 October 2016, from http://ww2. unhabitat.org/documents/ZimbabweReport.pdf

Tobias, J.M., Mair, J. \& Barbosa-Leiker, C., 2013, 'Toward a theory of transformative entrepreneuring: Poverty reduction and conflict resolution in Rwanda's entrepreneurial coffee sector', Journal of Business Venturing 28(2), 728-742. https://doi.org/10.1016/j.jbusvent.2013.03.003

UN (United Nations), 2014, UN data: Zimbabwe, viewed 23 April 2017, from http:// data.un.org/CountryProfile.aspx?crName=ZIMBABWE\#Economic

Wiklund, J. \& Shepherd, D., 2003, 'Knowledge-based resources, entrepreneurial orientation, and the performance of small and medium-sized businesses', Strategic Management Journal 24(13), 1307-1314. https://doi.org/10.1002/smj.360

World Bank, 2016, Zimbabwe overview, viewed 24 February 2017, from http://www. worldbank.org/en/country/zimbabwe/overview

Ziegler, C.A., 1985, 'Innovation and the imitative entrepreneur', Journal of Economic Behavior \& Organization 6(2), 103-121. https://doi.org/10.1016/0167-2681(85) 90012-5 